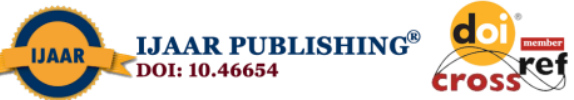

International Journal of Advanced Academic Research (Arts, Humanities and Education) | ISSN: 2488-9849

Vol. 6, Issue 4 (April, 2020) | www.ijaar.org

Journal DOI: www.doi.org/10.46654/ij.24889849

Article DOI: www.doi.org/10.46654/ij.24889849.a6426

\title{
THE ACADEMIC QUALITY ASSURANCE IN THE COLLEGES OF EDUCATION IN NIGERIA
}

\author{
ATANDA, A. I., Ph.D \\ Department of Educational Management, \\ Faculty of Education, \\ University of Ibadan, Nigeria. \\ Email: ademolaui@yahoo.com \\ Phone No: +2348024323231
}

And

ADENIRAN FESTUS ADEWALE

Department of Curriculum and Instruction,

School of Education,

College of Education, Lanlate Oyo State, Nigeria.

Email: adeniranfestus@yahoo.com

Phone No: +2348029122722, +2347069253464

\begin{abstract}
The role of the teachers is very essential in nation building. Colleges of Education provide a nation with professional teachers who are equipped with methodology and skills of teaching in pre-primary/Nursing, Primary and Junior Secondary levels of education in Nigeria. Essential, college of education are expected to provide full time courses in teaching, instruction and training and to conduct courses in education for qualified teachers. In order to achieve the objectives in colleges of education, quality assurance is required/needed. This paper examines academic quality assurance, reasons for establishment of colleges of education, concept of quality control and assurance; differences between quality assurance and quality control; roles and purpose of quality assurance in Colleges of Education in Nigeria, it equally lists some challenges of quality assurance in Colleges of Education. Likewise, the paper highlights some measures to facilitate quality assurance in colleges of education in Nigeria. The paper therefore recommends, among others, that government should improve allocation of fund to Colleges of Education, regular review and redesign the curriculum as environment changes with modern technologies and the welfare of the lecturer and non-teaching staff should be properly taken care of, with effective monitoring and adequate evaluation of all the units within the certification of colleges of education graduates in Nigeria.
\end{abstract}

Keywords: Academic Control, Quality Assurance, Colleges of Education, NCCE, Changes, Roles, Purpose, Challenges and way forwards. 


\section{Introduction}

The worth of education is established in its quality. In Nigeria, the academic quality assurance in educational institution has become an issue of major concern among education stakeholders. Quality assurance is designed to prove and improve the quality of an institution's methods, educational (input-processes and output/outcomes).

Assuring the quality of educational provision is a fundamental aspect of gaining and maintaining credibility for programing, institutions and education system as a whole.

According to Abiodun-Oyebanji (2014), quality is assured in education when all authorities responsible for the management of the system prescribe some minimum standards of operation at different levels. Universities, polytechnics, colleges of education and federal and state owned secondary schools respectively, having the educational regulatory agencies such as National Universities Commission (NUC), National Board for Technical Education (NBTE), National Commission for Colleges of Education (NCCE) and Quality Assurance Unit/Department are saddled with the responsibilities to oversee the affairs of the assigned institutions.

In the 80s, all Advanced Teacher's Colleges were transferred into Federal Colleges of Education and as at toady have risen to twenty-one (21) in number. Colleges of Education in Nigeria are owed by the Federal Government, State Government, Military (Army), Private individual and other non-governmental organizations. The annual report of 2009 and 2010 of National Commission for Colleges of Education (NCCE) indicated the approved Colleges of Education in Nigeria as follows:

\begin{tabular}{|c|l|c|c|c|c|}
\hline 1. & Federal College of Education & - & 22 & $=$ & $19.64 \%$ \\
\hline 2. & State Colleges of Education & - & 46 & $=$ & $41.07 \%$ \\
\hline 3. & Privately owned Colleges of Education & - & 35 & $=$ & $31.25 \%$ \\
\hline 4. & Polytechnics offering NCE & - & 07 & $=$ & $6.25 \%$ \\
\hline 5. & Other Federal NCE awarding institutions & - & 02 & $=$ & $1.79 \%$ \\
\hline & & & $\mathbf{1 1 2}$ & & $\mathbf{1 0 0 \%}$ \\
\hline
\end{tabular}

Source: NCCE Annual report 2019.

\section{Justification for establishment of Colleges of Education in Nigeria}

College of education is daily justifying its existence as a viable sector of Nigeria educational system and has provided Nigerians the following laudable opportunities/privileges:

To develop adolescent minds for national development;

$>$ Provision of middle level manpower in the education industry (Nigeria Certificate in Education NCE);

$>$ To improve professionalism in teacher education; 
Promote the gender equality and empowerment;

$>$ Improve standard of Basic Education in Nigeria;

Improved technical and science education for nation's youth;

$>$ Improved research activities;

$>$ More so, help in equal distribution of national resources, (sitting/establishment of Colleges of Education by religious bodies, private bodies, state government and federal government);

$>$ Reliable human capacity building;

$>$ Urbanization of colleges sites i.e. immediate community;

$>$ Improve the entrepreneurship training for Nigerian youths;

$>$ Helps in production of qualified teachers for Nations, Basic schools, Primary, Junior and Senior Basic schools;

$>\quad$ It gives room for direct admission of NCE graduates into Universities for further studies leading to acquisition of Bachelor of Education Degree, with other areas of specialization;

$>$ Avenue for continuing education for people that are working through the Colleges' Sandwich Programmes;

$>$ Assert to the present Government reformation agenda/change (educational change);

$>$ Involvement of private sectors;

$>$ Collaborative efforts with other sectors such as Agriculture, Vocational, Technological, mass literacy programme, mass media, heath, entrepreneurship, etc;

$>$ Colleges of education serve as action that support for UNESCO aspirations like Education for All (EFA), Millennium Development Goals (MDGs) etc; and

> Finally, collaboration with other relevant agencies like NTI, NABTEB, NCCE, UBE, NUC, JAMB etc. for National Development achievement in Nigeria.

Source: Opoola (2015).

\section{Concept of Quality}

Quality can be said to be outcomes of a product which is either good or bad. According to Babalola (2007), it is most defined as fitness of purpose in relation to the user and customer needs. It can also be taken to mean that the product conforms to standards, specification or requirements. Deluxe Encyclopedia edition (2010), defined quality as that which makes a being or thing such as it is, a distinguishing element or the characteristics of anything regarded as determined. Quality determines the total way of the features of a process, product or service or its performance.

The word quality comes from Latin word quails meaning "what kind of". Sallies (2002) observed that, quality can be seen from absolute and relative point of view. Quality from absolute point of view has to do with highest possible standard that cannot be surpassed. So to say in this regard, the quality of something can be said to be a part of its nature. 


\section{Quality Control and Assurance}

At times, Quality Control and Quality Assurance are used interchangeably; though they are quite different from each other. According to (Agbato, 2015), Quality Control can be defined as a process that is used to ensure a certain level of quality in a product or service. It is a process that reviews the quality of all factors involved in production. Quality control is a procedure or set of procedures intended to ensure that a manufactured product or performed services adhere to a defined set of quality criteria or meets the requirements of the customer/client.

These educational institutions, be it colleges of education, polytechnics, universities, are industry for human development. In every industry, there are inputs, likened to buyer process in order to transform into an output for the use of customers. Students are the end products and for them to meet the quality required, it means that, they must be able to teach, instruct, communicate and handle the curriculum of education at the Basic level (primary and secondary level). Anything short of this makes them sub-standard or faulty products/outputs.

\section{Quality Assurance}

Quality Assurance as defined by Quality Assurance Agency (QAA, 2004) is the means through which an institution ensures and confirms that the conditions are in place for students to achieve the standards set by it or by another awarding body. Quality assurance enhances quality in the educational sector and it is the process of taking deliberate step at institutional level to improve the quality of learning opportunities.

Frazer (1992), while looking at the place of quality assurance in school system opined that, quality assurance of teaching and learning in schools is to help identify unsatisfactory standard or quality in school programmes and then ensure that rapid action is taken to improve them: and since education is the basic instrument of economic growth and technological advancement of any society, colleges of education inclusive, then the issue of its quality; in term of availability of resources such as physical facilities, human resources, material resources, quality instructional delivery among others cannot be treated with kids glove.

Wikipedia (2010) refers to Quality Assurance as a systematic activity, implemented in a quality system so that quality requirements for the product or services will be attained/fulfilled. Sallies (2002) explained Quality Assurance as a process of activities before and during an event to prevent faults. In other words, it is about designing quality into process to attempt to ensure that the product is produced to a predetermined specification. Quality Assurance is a means of producing defect and fault free products. It involves consistently meeting product specification or getting things right first time and every time. The system that is put in place or the process is what is termed Quality Assurance. Quality Assurance is a complete system to assure the quality of products or services delivered. It is not only a process, but a complete system including control. Now, quality assurance is the 
systematic measurement, comparison with a standard monitoring of processes and an associated feedback that confers error prevention. In reference this understanding to Colleges of Education, Quality Assurance, will involve students enrolment/access or admission process, mode of instructions, methods of teaching and assessment, teaching practices, exercise and supervision, conduct and supervision of examination, marking and grading systems. The management goals and policy are all components that go along with Quality Assurance. This quality assurance is a multi-dimensional. Every segment/units/department of colleges of education must recognise its roles as complementing that of other and be ready to play its part effectively before we can have a very successfully achieved quality assurance.

Zecchary, Michael and Howard (2008) said that educational policies and practices entail weighty ethical and social issues because conflicts arise when different value systems are in play. In other words, subject teachers, classroom teachers, parents, administrators/management and government all have their own quotas/part to play in order to achieve Quality Control and Quality Assurance.

Aremu (2012) stated that the quality of instruction at all levels of education has to be oriented toward inculcating the following values within themselves:

a. Respect for the worth and dignity of individual;

b. Faith in man's ability to make rational decisions;

c. Moral and spiritual principles in interpersonal and human relations;

d. Shared responsibility for the common goal and society;

e. Promotion of physical emotional and psychological development of all children; and

f. Acquisition of competencies necessary for self-reliance.

\section{Attributes of Quality Education}

Agbato (2012) views the following indices as attributes of quality and standard in education as expected of lecturers. Lecturers must:

* Be prepared for whatever they want to do, in their lectures/teachings, setting of the examination questions, invigilation during examination, marking, result compilation and grading;

* Lecturer needs to be versed in their subject matter and update their knowledge in their various discipline from time to time;

* They should do the right thing at the right time which simply means that they should promptly and timely attend to schedules;

* Lecturers must be a man and woman of integrity, in order words, they must be honest, reliable, trustworthy and ready to carry out responsibilities and duties with less/little or no supervision;

* Be diligent, consistent and hard working;

* Be prepared for change when the need arises at any time;

* Employ the principles and attitudes of fairness and justice in all things; and 
* Exercise the fear of God and constantly be a role model to emulate by the students.

\section{Differences between Quality Assurance and Quality Control}

1. Quality assurance deals with process while quality control deals with product;

2. Quality assurance involves section of tools/equipment and materials while quality control involves inspection;

3. Quality assurance defines the process while quality control involves in testing;

4. Quality assurance is proactive while quality control is reactive; and

5. In quality assurance, it prevents the defects while quality control finds the defects.

\section{Roles and Purpose of Quality Assurance in Colleges of Education in Nigeria}

Adegbesan (2010) reiterated that the need for quality assurance in Nigeria Colleges of Education cannot be over flogged. It is the engine that drives the general restructure in Nigeria education system. Also, it focuses on internal processes and outputs, and it embedded the improvement of productivity and reduction of wastage.

Establishment of Quality Assurance and Control Unit in the college helps the lecturers and non-academic staff to be consistent, hardworking staff and not to be afraid/there is nothing to fear while to the indolent and lazy ones, might be seen as a means of witch-hunt of staff by management through assessment and monitoring exercise.

Likewise, Saba (2009) in Agbato (2015) refers education institution to a means of transport which requires quality fuel to function/run effectively. The quality of any institution of learning depends on its institutions, faculty/schools, examination system, resources, policies, curriculum design and their strategic planning of such institution. So to say, the relevance/importance of quality assurance in the achievement of quality among the colleges of education graduates cannot be overemphasized.

These are some of the roles/reasons/purpose of the Quality Assurance in our colleges of education in Nigeria:

1. Planning/organizing awareness and programmes sensitization: The directorate of Quality Assurance has to perform its duty to create awareness on the quality and the standard in the colleges of education according to the National Commission for Colleges of Education (NCCE) rules and regulations and mount series of sensitization programmes to enlighten and educate the college environment/community that quality cannot be compromised.

2. It assists in monitoring and assessment of instructions/supervision: These are another roles of Directorates to ensure consistent and thorough monitoring of the quality and standards of instructional delivery that are to be maintained in the schools and colleges in general, such as examination questions, continuous assessment of the students attendance of the lecturers etc. 
3. Collection of data and useful information: The Directorate of Quality Assurance is to generate formative data which can be useful for the improvement of the quality management and delivery of the Nigeria Certificate of Education in the colleges through proper monitoring and assessment exercises e.g. number of input, enrolment, output etc.

4. Accountability: The Quality assurance ensures how the financial resources available could be prudently and judiciously utilized. Likewise, it is to make the staff and management provide a basis of accountability to the government for their huge financial commitment to the courses of teacher education in Nigeria.

5. A feeling of happiness of clients and customers: The Quality Control and Assurance is a customer-driven process because they got what they want through its activities which will help fine-tune the best possible educational opportunities that will ensure that the society/customers and end users of the products are satisfied and contribute their quota to the development of the nation that they will be better prepared for the demand of the market place.

6. Relevancy: In Nigeria, to make our colleges of education relevant in education industry when compared to other tertiary institution of grade 7 in the country by producing highly qualified and qualitative NCE graduates. With this assistance of quality assurance the college helps to meet the challenges of competition by working to improve the quality of our services and curriculum delivery. It also plays the major role on the configuration of the status of an institution in the education sector.

7. Adequacy of the facilities: The Quality Assurance helps in determining the adequacy of the facilities available for quality control by ensuring that learners' learning is well supported with current, relevance and adequate resources and that, those actively involved both in school administration and teaching have clear job descriptions and know their job responsibilities.

8. Advisory Roles: Agbato (2015) sees the role of the Quality Assurance as to provide guidelines and advice on the standard of quality instructional delivery toward facilitating teaching and learning in the lecture rooms. Not only that, they are also to advice the management, committee of Deans, Academic Board on policy issues, quality and standard of learning from time to time.

9. Enforcement of laid down rules and regulations: National Commission for Colleges of Education (NCCE) that saddles the affairs of colleges of education has the laid down rules and regulations that govern the colleges. It is the right duty of Quality Assurance to ensure that every segment of the colleges complies to the laid down rules and regulations and doing the right thing the right way to the last letter as far as the issue of quality and standard of college are concerned.

10. Professionalism of Teaching Career: It is also the role of Quality Assurance to ensure that professionalism of teaching career is enhanced by ensuring that appropriate pedagogic practices in the right way are employed by the student teachers in the colleges of education during teaching practice in order to be professionally sound and competent. 
11. Evaluation/provision of periodic report: The Directorate of Quality Assurance through its activities must as a matter of fact provide a periodic report either monthly, quarterly, end of semester or session basis to the management for self-assessment records of the schools and college at large.

12. Feedback: The Directorate of Quality Assurance through its findings performs the roles of writing the feedback of their assessment to the management of the college in order to be up to standard. The quality assurance guides against defect in colleges of education process such as to read, search for information in different ways and clothings practically and follow-up during teaching practice.

\section{National Accreditation of the Colleges Academic Programmes}

The National Commission for Colleges of Education (NCCE) as bridge has given opportunity for a fundamental function of the quality assurance to prepare the colleges for internal and external accreditation exercise. Also, equally the role of the unit to carry out internal accreditation exercises on annual basis and submit the report to the college management and headquarters of NCCE. The college has to make appropriate provision to any area discovered for needs.

\section{Challenges of Quality Assurance in Colleges of Education}

Ajayi and Awe Bolupe (2008), Ayodele and Oyebanji (2008) and Fabunmi (2012) identified the factors which constitute the bane/challenges/problems of quality assurance in the Nigerian educational system. These include the points highlighted below: Depressed funding, population growth, inadequate and unqualified lectures/poor staffing, poor facilities and equipment, examination malpractices, corruption, quality of the students, wages and salaries, poor teaching and learning environment.

1. Depressed /Poor Funding: Funding of colleges of education has always been a major and persistent problem in Nigeria. However, the contribution of inadequate funding to poor quality education is enormous. Likewise, inadequate funding affects the provision of facilities and the recruitment of the desired manpower to implement the programmes that have been developed. This in turn affects the academic delivery in the colleges of education resulting in what Yakub (2002) called "a dull intellectual atmosphere". The UNESCO has recommended a standard budget allocation to educational sector to spend as 26\%. The Nigerian government has since 1999 been spending less on education. Jaiyeoba and Atanda (2005) remarked that fund is crucial in facilities acquisition, staff development (to cater for the enrolment increase) and for policy implementation. In the face of acute shortage of funds, other input suffer setback, which in turn influence the level of quality obtainable. At this point, poor/depressed funding has the following implication for Quality Assurance in college of Education:

- Inadequately funded research activities/awarding scholarship;

- Inability to meet the welfare and academic needs of the staff/staff development and students resulting in strikes and closure of institutions for months; 
- Inability to recruit and retain qualified lecturers; collapse of facilities and equipment;

- General frustration of staff leading to brain drain.

- The jettisoning of procedures and the enthronement of a dull intellectual atmosphere;

- Emergence of unedifying academic situation and the erosion of time-honoured standards academically and morally (Yakub, 2002);

- In effect, poor facilities and other learning materials, due to poor funding impede quality assurance.

2. Population Growth: As a result of government and societal attitude to teaching profession, teachers come last in almost everything in Nigeria. Many parents discourage their children from choosing the colleges of education as first or even second choices during UTME examinations. Due to this, the cut off points for colleges of education students is usually low. Therefore, 150 marks was considered for candidates seeking admission into colleges of education and polytechnic while 180 marks/scores and above was approved for universities admission.

The outcome effect of this scenario is that colleges of education now accommodate weak students that need serious extra effort to become qualified teachers for the nation's schools.

3. Poor Facilities and Equipment: Where learning facilities are not always available, such as poor state of classroom, offices, libraries, hostels and laboratories. The provision of the relevant educational facilities and equipment is vital in provision of quality educational services to all students in the colleges of education. However, the poor state of facilities and equipment has been a major challenge to quality assurance in colleges of education.

4. Wages and Salaries: In many states of the federation today, both teaching and nonteaching staff are faced with situation whereby they are owed arrears of salaries. The staff's salaries are no longer being paid as and when due. A strike action by teaching and non-teaching staff is now the order of the day in many of our colleges of education.

5. Examination Malpractice: In colleges of education, examination malpractice has undergone various forms and having a lot of experience of life, knowledge about a habit such as bringing pre-paper notes, textbooks into the examination hall, impersonation, calculator machine, bringing information of items on palm, currency note, clothing, under the private part of the body, socks, bribing invigilators and supervisors. Osagiede (2005) sees Examination Malpractice as implication on academic quality; quality and standard as mediocre performance (or not very good) are produced from any educational system that is fraught with examination malpractice.

6. Corruption: Anavberokhai (2007) viewed corruption as embezzlement; misappropriation and diversion of scarce funds meant for educational purposes further impoverish the sector. The negative effect of this is that there can hardly be any meaningful implementation of policy acquisition of facilities and libraries and ICT tools which are vital to effective teaching and research in colleges of education. 
7. Quality of Learners: As noticed by Akpochafo and Filho (2008), learners in Nigeria colleges of education and other higher institution of learning are not therefore serious and committed academically; they deliberately avoid the strain and vigour associated with higher education. Many of the learners/students go into lecture halls without textbooks and even writing materials like pens, pencil etc. Some of them recorded less than 50\% attendance at lectures and failed default in assignment. This is one of the reasons why it becomes difficult to get students to learn, to investigate, to research, to engage in independent study; they lack the culture of scholarship and hard-work to have good quality, and standard of learners can no longer be assured in colleges of education.

- Inadequate and unqualified quality assurance personnel;

- Excess workloads of quality assurance personnel's and absence of quality assurance policy are few of many of challenges confronting quality assurance of our colleges of education in Nigeria; and

- Absence of a comprehensive standard and quality assurance standard policy document, inadequate of synergy among relevant stakeholders in quality assurance project.

\section{The Ways Forward For Colleges of Education Quality Assurance for Future Development}

If quality and standard are to be assured in our colleges of education, a number of measures according to Babalola (2004), Aworanti (2012), Sele (2013) must be put into consideration.

1. Proper Funding: Proper funding is very critical to ensure quality in all levels of our educational system, most especially at the higher education level. Funds should therefore be adequately allocated to run, purchase instructional materials and manage colleges of education in Nigeria. Incidentally, the amount of money Nigerian government devotes to education is far lower than the $26 \%$ of government expenditure as recommended by UNESCO in 1999.

Sele (2013) said the Delta State government is doing a lot in this regard by granting subvention and promptly releasing fund to operate the colleges of education. Likewise, there is need for some integrity on the part of school management; so that funds for academic purpose must only be used for their original purposes and never diverted or misappropriated. Due to this, there is need for improved funding of colleges of education because promotion of high and improved quality and standard in college of education are often constrained by inadequate financial resources and underfunding.

2. Curbing Corruption: It is not a gainsaying that much of the financial resources meant for educational development in Nigeria had been diverted through corruption. As it has become imperative for this menace to be eradicated in Nigeria. Government of our country should therefore introduce stern measures to stop or eradicate corruption in the country. Erring individuals and government officers caught/found should be punished to 
serve as deterrent to others. Likewise, there should be proper tracking of both human and material resources to the education sector and educational institution to ensure proper, accurate and adequate accountability.

3. Curbing Examination Malpractices: The government should strictly enforce the laws against examination malpractice in Nigeria. Any student caught in the act should be punished to serve as scape goat/deterrent to others. The lecturers should be the role models to the students in refraining from being involved in examination malpractice. Also, the parents should perform their duty of inculcating high level of moral training standard on their wards so that they can refrain from examination malpractice in schools. Also, there should be creation of favourable environments for studies in colleges of education.

4. Motivation of Lecturers and Non-Teaching Staff: In as much as inadequacy of motivation has been identified as one of the causes of negative causes of negative attitude of lecturers and non-teaching in the colleges of education, government should give priority to lecturers' and non-teaching staff welfare in order to have good quality assurance outcome.

5. Befitting Infrastructure in the Schools: There is also the need for improvement in the level of infrastructure facility in schools. This will depend to the large extent, on the level of finding made available in the colleges of education. Also, Ibukun (2004) advocated for modern educational materials and packages to be consciously introduced that no programme, no matter how well intended, can succeed if adequate infrastructural facilities are not provided for implementation. Adequate materials/tools or facilities are every vital to the successful training and certification of products.

6. Conducive Working Environment: Very good and conducive environment for academic and non-teaching staff of colleges of education are essential for enhancement of productivity of colleges lecturers and other staff. A comfortable office is a good incentive for staying long for reading and carrying out researches in the colleges such as electricity, air conditioners, modern furniture, steel cabinets, internet and other needed by academic staff.

7. Staff Development and Welfare: Jaiyeoba and Atanda (2002) laid credence to staff development and welfare that the quality of lecturers in charge of training/teaching goes a long way in ensuring standards. Lectures should therefore be assisted to continue to undergo refresher courses, workshops, seminars and conferences, especially in their areas of specialisations, since lecturers' qualification and experience are very crucial to their courses mastery and delivery. Afemikhe (2007) also advised colleges of education authorities to lay emphasis on teachers training and re-training to acquaint them with development in assessment practices that can provide more valid and reliable scores. One agrees with these suggestions and urges colleges of education to encourage staff to attend seminars, workshops and conferences. Effective teaching cannot be achieved without sound knowledge of new technologies of teaching.

8. Communication: Ministry of Education at federal and state levels should be made to make the line of communication, whereby constructive and purposeful disciplinary 
advice could be given with the aim of improving the quality of teaching and learning wide open. Moreover, keeping watchful eye on the impact, process, output and the atmosphere/environment of an education system to ensure that things keep going in the right direction in accordance to set standard will facilitate assurance of quality in the colleges of education.

9. Private Sector Participation: The government should give room for the private sector participation and must be encouraged to ensure quality in our education system, colleges of education inclusive.

10. External Academic Quality Assurance Mechanism: To the adoption of benchmarks by National Commission for Colleges of Education (NCCE) to evaluate and maintain quality in all the colleges of education in Nigeria.

11. Internal Academic Quality Assurance Mechanism: This is a unit in each college of education to monitor and evaluate teaching-learning process. Omoregie (2005) listed the duties expected of the academic quality assurance unit to include in their activities such as follows:

- Supervision of curriculum design, content and organization;

- Supervision of curriculum implementation (course by course in each school in colleges of education) - what portion of a 16 weeks semester is issued for actual teaching;

- Make sure that each lecturer marks the students' class attendance and must be kept;

- Students progression and achievement including attrition/drop-out rates;

- Student support, and guidance and counselling;

- Periodic assessment of human and materials resources available to each programme;

- Feedback to all level following data analysis to facilitate continuous improvement in quality;

- Tracking of the graduates for feed-back from employers; and

- Continuous interface with Quality Assurance Agency and professional bodies to keep abreast with latest information.

12. Evaluation: This involves arranging and reviewing data collected from schools in the Colleges of Education to draw a conclusion on the status of the programme and to ensure how best we could improve the mal-functional area. Quality Assurance strategy is to see how the colleges can be assisted to improve the present level of performance (Adeniran and Olorode, 2014).

13. Feedback: Finally, Quality Assurance cannot be completed without constant check to evaluate conformity, complacence and progression of the product or services. It is very important that the quality assurance that checks the quality through National Commission for Colleges of Education (NCCE) to report back to appropriate authorities any form of deformity, inadequate compliance or confirmation toward the set standard to ensure that the final product (graduate) from every stage involved in training of teachers in Colleges of Education adheres to the recommended standard (Adeniran and Olorode, 2014). 


\section{Conclusion}

The request for quality assurance in colleges of education level of education cannot be overstressed as the ensuring quality and standard in the colleges of education is a collective responsibility of all stakeholders. All involved people must be determined, committed and have assurance in all things that it take to achieve available resources donated by the government, parents and community who are investing in the education sector will not be wasted.

\section{Recommendations}

Government should improve allocated fund to colleges of education in Nigeria to meet the UNESCO minimum requirement for developing countries. Also, the government should let their yes be yes and no be no in honouring any form of agreement reached with the workers' union/group in our Colleges of Education to avoid unnecessary strikes or any form of face-off between the union/group and the government;

For quality assurance to be well assessed, the learning environment in Colleges of Education in Nigeria must be conducive by having the following amenities such as regular supply of electricity, internet, water, security, offices, standard classroom, laboratories, libraries, recreational center, transportation and hostels must be constructed to meet the international standard that will enhance learning in our Colleges of Education;

There is need to regularly review and re-design the higher education curriculum in Nigeria to make it more practical and market oriented to produce skilled and highly educated NCE graduates that are needed by private and public sectors within and outside the country;

The colleges of education in Nigeria should employ qualified academic staff. Those employed should be re-trained and allowed to undergo seminars, workshops and conferences;

Colleges exchange programmes on regular basis for effectiveness and be familiar with latest technologies in teaching that could enhance the quality of Colleges of Education in Nigeria; and

Finally, Colleges of Education should endeavour to communicate their goals, mission and vision to students before admission so that they will be part of goal achievement process during their studentship. 


\section{REFERENCES}

Abiodun-OyebanjI O. (2014). Issues and Prospects in the Management of university Education in Nigeria. In B. O. Emunemu and F.S. Akinwumi (eds) Educational Management in Africa. Ibadan; Giraffe, Book.

Adegbesan, S. (2010). Establishing Quality assurance in Nigeria educational system; implication for educational managers. Educational Research and Reviews 5(7). 380-384.

Adeniran,F.A.and Olorode,O.A.(2014) "Towards enhancing quality assurance in teacher education for development in Nigeria" Akoka Journal of Education 6(1) 45-54.

Agbato, S. 0. (2012). Ensuring and Standard of Academic Matters in the College. Paper presented at the work-shop organized for Academic Staff of Federal College of Education (special) Oyo, October 25.

Agbato, S. O.(2015). The Role and purpose of Quality Assurance in College of Education.In A. O. Adebimpe and Ajobiewe T. (eds) ). A festschrift in honour of Dr. Emmanuel Olufemi Adeniyi, Abeokuta, Pee and Gee press and publishers.

Ajayi \& Awe, B. (2008). Challenges of Autonomy and Quality Assurance in Nigeria Universities in Babalola J. B. (Eds). Towards quality in African higher education ppl03-1 13. HERPNET Publications; Ibadan: Wale Crown Venture.

Akpochafo,W.A, Filho,W.L.(2008). "An Overview of the barriers to Curriculum Implementation in Nigerian Universtsities" International Journal of Continuing Engineering Education and life- long learning.

Anavberokhai, M. O. (2007).Studies in Education 9 (1-2), 63-67.

Aremu, G. B. (2012). Educators for Reliance: The Example of Vocational and Technical Education. A Lead Paper presented at the $5^{\text {th }}$ National Conference of the School of Vocation and Technical Education, Federal College of Education (special), Oyo, Oyo state, 8-12 May.

Atanda, A.I. (2014). Quality Education for sustainable development; A task for every stakeholder; Educational Management in Africa In B. O. Emunemu and F.S. Akinwumi (eds) Educational Management in Africa. Ibadan; Giraffe, Book.

Aworanti, O. A. (2012). Quality Assurance in Business Education. A lead paper presented at the $24^{\text {th }}$ Annual National Conference organized by the Association of Business Educators of Nigeria at Federal Polytechnic, Nekede, Owerri, Irno state, 16-20 October.

Ayodele, J. B. \& Abiodun-Oyebanji O. (2008). The issues of quality assurance in Nigeria universities. In Babalola, J. B. (Eds) Towards Quality in African higher education, pp 142-149. HERPHET Publication, Ibadan. Wale Crown Venture.

Babalola J. B. (2004). Management of Primary and Secondary Education in Nigeria NAEAP publications, Ibadan; His lineage publishing House.

Babalola, J. B. (2007). Revivalizing quality higher education in Nigeria; Options and strategies in J. B. Babalola, G. O. Akpa, A. O. Ayeni and S. O. Adedeji (Eds.) Access, equity and quality in higher education. NAEAP publication. 
Bashaka, B. C., Muhanda, M. B. and Kittoba (2009). Programmes Based Educational Uganda Management Institute. A Correlational Approach, NCHE, Kampala.

Edward Sallis (2002). Total Quality Management in Education. Third Edition.

Frazer, M. (1992). Quality Assurance in higher Education. In ACRAFT (Eds) Quality Assurance in higher education. Proceedings of an international conference, Hong Kong Londin; Falner.

Ibukun, W. O. (2004). Educational Management: Theory and Practice. Ado-Ekiti Bamgboye and Co. press (Nig) Ltd.

Jaiyeoba, A. O. \& Atanda, A.I (2005) "Quality sustainance in Nigeria educational system challenges to government”. In G.O. Akpa, S.U. Udoh \& E.O. Nigeria, Jos: The Nigerian Association for Educational Administration and Planning (NAEAP).

National Commission for Colleges of Education (2019). Annual Report February 2019, Abuja.

Omoregie, N. (2005). July, Re-packing Secondary Education in Nigeria for great dynamic economy. Paper presented at the $2^{\text {nd }}$ Annual National Conference of Association for Encouraging Qualitative Education in Nigeria (ASSEDEN).

Omoregie, N., (2005). Studies in Education: 8,128-134.

Opoola, B. T. (2015). Teacher Education Administration in Nigria: A case study of college of educcetion system. In O .A and T. Ajobiewe (eds). A festschrift honour of Dr. Emmanuel Olufemi Adeniyi, Abeokuta, Pee and Gee press and publishers.

Osagiege, F.I,(2005). Studies in Education 8,77-80.

Quality Assurance Agency (2004). Quality Assurance and Quality Enhancement in elearning.http://evidencenet.pbworks.com/w/page/19383515/Quality\%20assurance\%20and $\% 20$ quality\%20enhancement $\% 20$ in $\% 20$ e-learning

Saba Rana, (2009). Quality Management in Higher Education - A Perspective: Proceeding $2^{\text {nd }}$ CBRC, Labere, Pakistan-November 14.

Sele, S. E. (2013). Academic Quality Assurance in the Colleges of Education; challenges and ways forward for future development. International letters of Social and Humanities Swenees. Vol. 13. pp 1-9 retrieved online at www.seipress.com/ILSHS. 13.1 on $\underline{25 / 10 / 2013}$

UNESCO Nigeria (1999). The State of Education in Nigeria,UNESCO: Lagos Offices.

Wikipedia (2010). Professionalization retrieved from http://enwikipedia.org /wiki/profession.

Yaqub, N.(2002). Higher education in Nigeria in perspective. Paths to the sustainable of higher education in Nigeria, SSAN, Abuja, 12-20.

Zacharry, S., Micheal, C. \& Howard, G. (2008). Exercising Quality Control in Interdisciplinary Education: Toward and Epistemologically Responsible Approach; Journal of Philosophy of Education, Vol. 42, No. 3-4. 